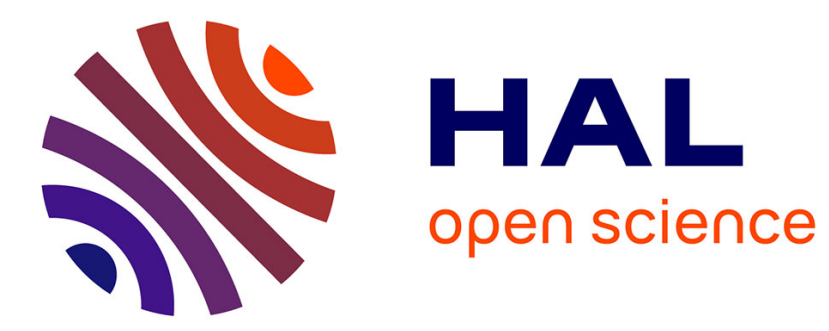

\title{
News cultures, security and transnational belonging
}

\author{
Sadaf Rizvi
}

\section{To cite this version:}

Sadaf Rizvi. News cultures, security and transnational belonging. European Journal of Cultural Studies, 2007, 10 (3), pp.327-342. 10.1177/1367549407079705 . hal-00571547

\section{HAL Id: hal-00571547 https://hal.science/hal-00571547}

Submitted on 1 Mar 2011

HAL is a multi-disciplinary open access archive for the deposit and dissemination of scientific research documents, whether they are published or not. The documents may come from teaching and research institutions in France or abroad, or from public or private research centers.
L'archive ouverte pluridisciplinaire HAL, est destinée au dépôt et à la diffusion de documents scientifiques de niveau recherche, publiés ou non, émanant des établissements d'enseignement et de recherche français ou étrangers, des laboratoires publics ou privés. 
Copyright (C) 2007 SAGE Publications Los Angeles, London, New Delhi and Singapore

Vol 10(3) 327-342; 1367-5494 DOI: $10.1177 / 1367549407079705$ www.sagepublications.com

\section{News cultures, security and transnational belonging \\ Cross-generational perspectives among British Pakistani women}

\section{Sadaf Rizvi}

Oxford University

ABSTRACT Muslim women have often been stereotyped as being trapped in an oppressive and patriarchal system that neither provides freedom of expression nor develops their full potential. This study addresses such 'misconceptions', highlighting the ability of British Muslim women to construct their religious, national and gender identities by engaging in lively debates and questioning what appears to be unjust. Dominant public and media discourses currently often equate Muslims with 'terrorists'. Muslim women challenge this conception by participating in news cultures and negotiating their transnational citizenship. This study shows that the religious and

political cultures of families shape women's perceptions and experiences of security and transnational belonging, rather than education.

KEYWORDs British Muslims, gender, integration, media, multiculturalism, news culture, security, terrorism, transnationalism

\section{Introduction}

In recent debate about the social position of Muslim women in different parts of the world, some argue that they are 'carriers of culture' and embodiments of collective honor (Archer, 2002), even if they migrate away from the patriarchal systems of their home countries (Shaw, 2000), and many researchers highlight Islamic, traditional and gendered customs underpinning oppression (Afshar, 1985; Odeh, 1993). Others view arguments about the subordination of women as overstated (Abu-Lughod, 1986; El-Guindi, 1981; Fernea, 1998), highlighting variation in women's ways of living and thinking (Bodman and Tohidi, 1998; Ghazal Read and Bartkowski, 2000; Moghadam, 1994) and the exercise of independence in domestic as well as public domains.

This research explores the perceptions of a multi-generational group of British Pakistani women about security, belonging and integration in 
British society, in relation to the availability and take-up of multilingual news sources. It shows them to be actively involved in negotiating their sense of plural and multilayered identities and transnational citizenship by participating in different available news cultures. Family discussions help them to form opinions about terrorism and security, to construct or challenge relationships with the outside world and to draw upon resources, notably including Islam, in order to find their own ways of dealing with the problems of 'human security' (Eriksen, 2005) prominent since 9/11. The first section discusses the different sources of multilingual news used by the women. The second section analyses how they interpreted the news of the 7 July 2005 London bombings. The third section examines the implications of terrorism and anti-terror polices in their lives.

\section{Method}

Five group interviews were conducted with a total of 27 middle-class Pakistani Muslim women in London, Oxford and Slough between December 2005 and February 2006. Each group consisted of five to six women of different backgrounds, generations, education levels and languages. All considered themselves to be practising Muslims. Most used multilingual and multi-ethnic news sources (British, Pakistani and beyond). Their ages ranged from 20 to 65 years; educational qualifications from nil to doctorate. Their ethnic groups and regions of Pakistan included Balochistan, Punjab, Sindh, North-West Frontier Province and Kashmir. The interviews were mainly conducted in Urdu and English, but some were more comfortable expressing themselves in Punjabi. Most (20) were housewives; others were working women (three), students (two) or unmarried and living with parents (two). With regard to residence in Britain, five were born and brought up in Britain, six had lived in Britain for 22 years or more, and 16 for less than 15 years. Of these, eight came as marriage migrants, four to join family, and four as students or spouses of students. The chief differences lay in their educational capital, reasons for migration, the profession of family members and the presence of politically active men in the family. All the participants have been assigned pseudonyms.

Most had never participated in such an interview and some were slightly nervous. Even a few elderly women considered themselves 'naive' and less knowledgeable, and were initially hesitant to express themselves in front of younger or more educated participants. Most became relaxed but some remained shy. However, when discussion turned to Muslims' identity and security there was a sudden increase in participation as they invariably spoke of their experiences of 9/11, the wars in Afghanistan and Iraq, riots in Paris and the earthquake in Pakistan.

My insider-outsider position was fruitful. As a Muslim Pakistani I was an insider: they could talk in their own language and cultural frame, 
for example, frankly discussing feelings of being discriminated against due to the 'unfair' media image of Muslims. But I was also an outsider: as a student living in the UK and intending to return to Pakistan, they considered me less knowledgeable about UK culture and needing to be informed. This made them still more open.

\section{Discussion}

\section{News cultures: western, 'apna' and Islamic media}

The London bombings of 7 July 2005 (7/7) were a subject of great concern and a topic of everyday discussion for the participants. They watched TV, read newspapers, listened to the radio, browsed the internet and made telephone calls within and outside the UK. They followed news in English, Urdu and Punjabi, mainly on British and Pakistani TV channels. Kinship networks were a significant source of information exchanged by word of mouth. Fears experienced and shared within the family, commentaries by husbands, news brought home by children, information from relatives in Pakistan and abroad were frequently reported with conviction and considered to be truth. The relevant media fall into three categories: western, 'apna' and Islamic.

\section{Western media}

Also referred to as 'English media', this includes TV and radio channels, newspapers and websites: for example, BBC, CNN, ITV, EuroNews, Radio 4, the Sun, Independent, Daily Mail, some local British newspapers and Yahoo! news. Western media was more popular among the younger participants, students and those who had been born and brought up in Britain, partly because they had a better command of English. They watched news, documentaries, dramas, movies, quiz competitions and talk shows, with and without their families; while doing housework and during leisure time. Women with limited understanding of English reported watching English channels only when family members more comfortable with English watched them. But following $7 / 7$, many of the women watched English channels.

Western media was regarded as more technologically advanced in terms of detailed and live coverage, and as credible in supplying news about natural disasters such as the Asian tsunami or the Pakistan earthquakes. The participants found that they were better informed about the earthquakes than relatives in Pakistan. But its coverage of terrorist events, especially those concerning Muslims, was viewed as 'biased', 'unreliable' and 'leftist', working to 'sensationalize the event' and 'promote racism'. It was perceived to downplay the violence provoked by non-Muslims, particularly within Muslim countries, and to exaggerate what Muslims might do in reaction to the terror that they have suffered for decades:

Hanifa: I think most of them ... almost of all them were sensationalizing the event. 
Naima: Yes, that's true.

Nazima: ... I don't know if you watched BBC ... I mean, they are all one-sided and I don't really trust what I read on any of these newspapers. They would quickly jump on and say they were Al-Qaida, they were Muslims.

Saima: They start blaming Muslims immediately without investigation ...

Asma: Obviously the day after, everyone is so emotional, to print it the very next day, of course, it's going to create a lot of hatred.

Western sources of news were mistrusted and seen as exacerbating anger and hatred for Muslims by presenting what 'they' wanted people to hear. Later in the interviews, the participants did appreciate the fact that some western sources covered the news of 'backlash' or 'reprisal' attacks. But most western sources were thought to be 'one-sided' and highly shaped by censorship: 'corrupt politicians' and the 'police' were regarded as manipulating journalists and editors, and hence controlling the news. This view is perhaps based on their understanding of Pakistani media, where politicians have powerful influence.

Despite these criticisms, all the women continued to obtain news from these sources, regularly or occasionally. One suspects that the extent of reliance on English channels was more than a matter of language. The western media form an important link between the women, their British citizenship and their being British. As Berthoud et al. (1997) suggest, Muslims are carving out their space in Britain. Watching news on British $\mathrm{TV}$ is about knowing what is going on in what is now considered hamara mulk ('our own country'). Watching British TV channels is part of being British: in this case, the media serve to create or strengthen an emerging identity.

\section{Apna media}

'Apna' means 'one's own' or 'our own': Pakistani news sources, i.e. TV channels such as the state-owned PTV, private channels Geo, ARY, Aaj, and popular newspapers such as Daily Jang and Nawa-e-waqt. Also referred to as 'Urdu media' (this being the chief language used), this was most popular among older women and housewives newly arrived in the UK (i.e. those with limited English). They subscribed to Urdu channels to watch detailed Pakistani news, as well as dramas, cooking programmes, movies and special programmes for the Eid and Basant festivals. Many hoped to encourage their children to learn Urdu (many also tried to visit Pakistan frequently with their children to familiarize them with Pakistani language and culture). Nargis (48), a housewife with four children, with 12 years of formal education in Pakistan, had lived in Slough for 22 years:

My children watch English news but when I watch it with them, I cannot understand some words, obviously because English is not my language, therefore, I like Urdu channels. 
As for newspapers:

Yes, Jang only. My husband brings it every day. We are reading it since beginning. We don't feel the need of reading any other newspaper ... But, my children do not take any interest in Urdu. As they are growing up, they like to use English more.

Her preference for Urdu is, again, more than a matter of language. British Pakistanis tend to maintain their ethnicity and many features of their culture and social organization have survived for decades (Shaw, 2000; Werbner, 1990). Reading the Urdu newspaper 'since beginning', feeling no need to read any other and wanting children to learn Urdu, are a means of retaining a Pakistani identity. Nargis' daughter Asiya (21), born in Slough, made greater use of western media. She equally enjoys watching Urdu channels but prefers English channels, newspapers and websites. She uses many more news sources in different media than her mother.

Apna media is considered less technologically advanced than western media but is rated much higher in terms of representing Muslims and portraying the injustices and miseries suffered by them worldwide. Through the apna media people became aware of the problems facing Muslims, from murder to unnecessary checks at train stations, comments to women on the street and so forth:

Ambreen: I think Pakistani channels were favouring Muslims. They said that Muslims are now being targeted in England after 9/11 in the US.

Sundus: Yes, Pakistani channels said that it was not our fault. The president said that.

Rumana: He said that the terrorists were not Pakistanis.

Bilquis: Because all those boys were British-born, they were raised here so they were British. They had no connection with Pakistan.

Apna media were seen as supporting and defending Muslims. President Musharraf's speech (telecast on Pakistani channels), describing the $7 / 7$ terrorists as British not Pakistani, was felt to have helped a great deal in restoring a sense of security which was otherwise shaken by the western media. ${ }^{1}$ As watching western media is a part of being British, and watching apna media is a part of being Pakistani, switching between the two may be a way of managing, and striving for, security (Eriksen, 2005).

\section{Islamic media}

Islamic media means print media such as the UK monthly The Muslim News and TV channels such as Quran TV (QTV, part of the ARY network, broadcast in Urdu and Arabic) and the Islam Channel (UK-based, Englishlanguage). One participant also listened to Koranic recitations and Islamic talks on the radio. The term 'Islamic media' is used irrespective of language or nation. The women clearly distinguished between channels with a purely religious character and distinctly Pakistani channels. Islamic 
channels were valued for the religious information provided through talks, discussions on the ahadith (sayings of the Prophet Muhammad) and Koranic recitations. Women kept their TVs on while Islamic channels played, so as to have barkat (the blessing of Allah) in their homes. Perhaps for this reason the Islamic media were equally popular among young and old women. Those who reported watching Islamic media the most had nothing in common except, perhaps, degree of religiosity. Nargis, for example, fulfils her religious obligations such as prayer, fasting and charitable giving, wears the hijaab and is training her children to become devout Muslims. She described QTV as 'a good channel' simply because ‘it provides Islamic information'. It broadcasts in Urdu and conforms to her own religiosity. A number of other women reported special interest in discussion programmes on issues such as the rights of women in Islam, the concept of riba (financial interest, profit) and the similarities between Islam and Christianity.

The Islamic media supersedes the idea of transnationalism as Muslims in Britain turn to Islam as a source of identity, irrespective of national origins (Halstead, 1986). In the face of sociopolitical insecurity, religion enables people to maintain inner security, reinforces social ties and strengthens group structures. News cultures and Islamic channels work hand-in-hand to provide security.

\section{7/7: discourses of Pakistani women}

Factors including religion, kinship and individual feelings of anger, hatred, guilt or fear were involved in the women's reaction to the news of $7 / 7$. Some were shocked or cried, or thanked Allah that they and their families were not at the places where it happened; some wished it was a lie; some felt sympathy for those who were affected. They hurried to call family members or to pick up children from schools. For most, the news aroused feelings of dar (fear) and ghussa (anger). They feared a backlash. They felt anxiety about their personal safety, fear for the future of children in this country or of problems that their husbands might have to face at work, as well as other challenges to the Muslim community, such as those after $9 / 11$. When they then heard that Muslims were being blamed for the bombings, this provoked anger at being blamed with little evidence and at the stereotyping of Muslims as terrorists. Feelings of fear, anger and in some cases desire for revenge, were followed by a feeling of insecurity, which led the women towards religion and family.

\section{Media coverage of the London bombings: 'a conspiracy'}

The main theme that most of the participants identified was that the coverage of $7 / 7$ reflected a conspiracy against Muslims by the western media, a conscious effort to equate 'Muslims' with 'terrorists' and to present Islam as a religion of violence. The participants believed that the bombers were identified as Muslims and Pakistanis even before their religious and national identity was known. 
Husna (32), a marriage migrant living in the UK for the last five years, found the coverage highly predictable. A graduate from Pakistan, she uses a variety of news sources to follow news around the world, and stated that her participation in news cultures post 9/11 led her to guess immediately that Muslims would be blamed for $7 / 7$. This frightened her on both the personal level and at the level of the larger Muslim community. Husna is a housewife with two daughters. On the day of the bombings she had dropped her daughter at school and came home to find BBC broadcasting the breaking news. She checked ITV News, Channel 5, EuroNews and Sky, noting the same news and images on all channels. In her view, this had the function of 'creating panic':

It's a big conspiracy against Islam and Pakistan. They want to develop a hatred for Islam among the public and therefore they kill their own people after every few days so the public thinks that Muslims are doing such terror. It is also linked to Iraq ... They want to divert the attention of Muslims. They want to show that it is not only Iraqis who are suffering, their people are also dying and that they are dying because of Muslims.

Based on her reflections upon past terrorist incidents, Husna linked global politics, the occurrence of terrorist events and the media's role in shaping public opinion. She was convinced that such events are pre-planned and strategic, and that their implications for different faith groups are precalculated by the planners. Similar responses came from women of all ages, educational levels and occupations. Sonia (34), an unmarried university student, referred to the 'differences between Muslims' way of life and non-Muslims' way of life' (such as the separability of religion and social life for non-Muslims) growing into hatred and conspiracies. Naima (54), a housewife and a very devout Muslim, believed that the rapid spread of Islam and high rate of conversions threatened the West, so efforts were made to give Muslims a bad reputation. Rehana (42), a part-time worker born and educated in the UK, felt that Muslims' reluctance to integrate fully in western countries (for example, by drinking alcohol) gave rise to such conspiracies.

Saima (55) is a housewife with little education, whose husband and sons are actively involved in organizing Islamic activities in the city, while her brothers are involved in politics in Pakistan. She became very angry when discussion turned to the news of $7 / 7$ on British TV:

I am quite emotional when it comes to Muslims. In case of 9/11 they showed Americans screaming to such a high extent. I argue, why don't they show Muslims crying in Palestine? Why not? Is it because they are big countries claiming equal opportunities? Why don't they bring crying Muslims on the $\mathrm{TV}$ ? In the newspapers? In reality so much happens against them.

Saima does not seem to dispute the news story itself, but instead questions the justice of media trends. Saima's participation in the discussion (at this point more animated than that of the better-educated participants) 
was linked with the political culture of her family. Similar views expressed by other participants reflected the emotional involvement of women in the discourse of media and Islam, the connected religious debates and the discussions that take place within their families.

\section{Security policies: US, France and 'our Britain'}

The participants were keen to draw comparisons between $9 / 11$ and $7 / 7$, which was predicted to have similar, although less severe, implications for Muslims. The western media were seen as unfavourable to Muslims, but the British media were better than the American in providing public information through documentaries, talk shows and news coverage. Tony Blair's policy was regarded as better than George Bush's. Initiatives taken to control the backlash (e.g. police patrols outside mosques, announcements that the Muslim community in the UK was not to be blamed for the terror) were much appreciated. Anti-racist initiatives by some English employers were also reported and admired. When Marium commented, 'Media can create hatred between the nations', Husna elaborated:

9/11 is the biggest example. So much hatred has been created for Muslims. I was there at that time when they attacked Afghanistan. They would show the news of Afghanistan and say, 'Take a break', and you know what they showed in the break? The crying people, the families of those who died in 9/11. They wanted to convey that although there was war in Afghanistan, but do not forget what Muslims have done to Americans. And people in America are crazy, they believe in anything they are told, it was all because of the order of the US president.

The US's strategic policies were seen to promote hatred of Muslims in contrast to the UK, where some efforts were made to promote peace. Comparisons were also made between the UK and other European countries, particularly France, where Muslim women faced restrictions on wearing the hijaab. At this point the participants expressed a strong sense of belonging to Britain and valuing their British citizenship. They reflected that Muslim women in Pakistan enjoy religious freedom, but face problems that restrict their development: lack of educational opportunities, cultural restrictions on jobs, dowry traditions, criticism for late or non-marriage and lack of public support for women in need. They enjoyed freedom from all these problems in the UK. Pakistan might be on the road to development and offering many more opportunities to women, but being British enabled them to live a more 'sophisticated' life. It was a matter of pride and great good fortune, something for which they were blessed by Allah.

\section{Allah is the most powerful, the most trustworthy}

It was striking that the women tended to relate things to Allah, pray to Him for safety, leave the incomprehensible to Him and trust that only He knows the truth. Terrorist events were explained in the light of global politics, but the consequences were to be sorted out by Allah. The women 
reported that on hearing of the $7 / 7$ blasts, they had prayed to Allah for hifazat, the safety and protection of family members, the Muslim community and those affected. Nargis said:

I keep praying to Allah as I worry what will happen if [the] media keeps saying such things about Muslims.

Husna, unable to understand the 'insanity' of 'media controllers', stated: 'God knows better why they are doing so.' Madiha (37), a housewife living in the UK for 12 years, said: 'To be honest, I don't trust any source of information ... I only trust God.' Naz (26), a newly-married woman, unwilling to accept any barriers to her mobility, relies on Koranic verses for the courage to go out:

You do feel uncomfortable when a terror like this happens ... but we have to go out anyway, we cannot stop. In such a situation, I recite ayat-ul-kursi and go.

Others also mentioned ayat-ul-kursi (The Throne Verse), a verse from the Koran recited by Muslims for safety in times of danger (Surah: The Cow, verse 255). Their faith performed a psychological function as they turned towards 'the Powerful' in a state of powerlessness. Praying with a belief that 'He' is there for their hifazat gives them strength to cope with what they find uncontrollable and incomprehensible. As Dupuis and Thorns (1998) argue, home is a locale where people can attain a sense of ontological security in a world which is experienced as threatening and uncontrollable. Here, religion provides ontological security, a sense of control and a context for day-to-day routines.

The phenomenon of 'suicide bombing' was also interpreted in the light of religion. The idea that the terrorists were 'true believers' was rejected vigorously. 'The meaning of Islam is peace; a true Muslim can't do that,' said Aliya (27), a young educated housewife, newly arrived from Pakistan. 'We should think in terms of what Koran says, we are not meant to take lives unjustly,' commented Hadiya (20), an unmarried British-born student. She had got into an argument with a relative in Birmingham who justified the bombings as a response to terror in Muslim countries. The right response, for her, should be jihad against anti-Islamic forces rather than the killing of innocent citizens. Muslims justifying the terror were considered 'extremists'. All saw the bombing as 'Islamically incorrect' and criticized the terrorists for misinterpreting Islam and damaging the reputation of the entire Muslim community. The women were firm that such terrorists cannot be regarded as shaheed (martyrs) or mujahid (righteous fighters), as some extremists suggest. However, there was sympathy for the emotional state of the bombers. They were assumed to have been 'forced' into such attacks 'out of desperation' and helplessness. Later in the interviews, the women emphasized the need to explore and broadcast the factors that lead to such attempts. 


\section{Because 'they' say so}

The women's tendency to obtain and trust news from family members was mentioned earlier. News provided by relatives was considered to be highly trustworthy. Some of the participants became aware of the $7 / 7$ attacks only through telephone calls with relatives. Details of the incident, police actions, transport disturbances, the death toll and so on had been learned entirely through word of mouth, until the whole family gathered to watch TV news late in the evening. In the following weeks, long discussions had taken place between family members on the event's causes and the implications for the Muslim community. The ideas discussed during the interviews here were based on those discussions.

Men's reports and ideas were regarded as the most reliable on account of their perceived political knowledge and sensitivity. The views of husbands, brothers and sons were considered to be based on deep intellectual analysis or first-hand observation. It was made clear that the purpose of the interviews in this study was to explore women's perceptions, but the mothers were firm that the interviews should have been conducted with their sons: only then would it have been possible to obtain an accurate picture of what the media was doing to Muslims.

Hanifa (58) has been living in the UK for the last 10 years. She decided to emigrate when her husband died and her son - working in the UK for 18 years as a general practitioner - invited her. She spends most of her time praying and reciting the Koran and pansurah verses. She does not watch TV for entertainment but watches the news on BBC and Sky every morning. When in Pakistan she watches the PTV 9pm news every day. However, her most important source of information is her son, who keeps himself up-to-date about news around the world. When 9/11 happened, he called her from work and told her what was going on in the US. Similarly, when $7 / 7$ happened, he read different newspapers, checked websites and commented that Muslims were being blamed without enough evidence. Her son's knowledge of current affairs, his interest in political issues and his ability to draw conclusions was a matter of pride for her. She trusted his views entirely. She felt no need to read newspapers as her son could brief her thoroughly about any event. Her daughters, whom she called regularly, were an additional source of news from Pakistan. Through them, she came to know the stories of people who died in earthquakes and the ordeals that their families had gone through.

Many other women's views were shaped by male family members. Phrases such as 'meray bhai nay bataya' ('my brother told') or 'meray husband nay kaha' ('my husband said') were used frequently. In addition, translations provided by children were a significant source of knowledge. However, the more educated participants and unmarried students based interpretations on their own reading or media use, such as Sonia (34), who came to the UK four years ago to pursue a $\mathrm{PhD}$. She has always relied on newspapers, websites and journals for information. Moreover, women's 
reliance on male family members cannot be equated with subjugation or subordination. Faced with the problem of the unknown or the unexplained, the women turn to men because they are perceived to be more exposed to the world outside the home, including the sociopolitical climate, and hence to have greater knowledge of it. This is another way of attaining security. Pakistani women turn to their families when the world outside home is threatening or insecure. News serves as a communication resource between men and women, where the men's role is to provide knowledge and support rather than oppression.

\section{Threats and insecurities: implications of terrorism and anti-terrorism policies}

Media coverage of the $7 / 7$ bombings seems to have increased the threats and insecurities that Muslim women experienced after $9 / 11$. Some of their stories demonstrated anxieties and threats, including acts of racism, which they (and their relatives and friends) faced in everyday life. The Londonbased participants were more directly affected by the consequences, but insecurity was experienced by all. The following stands for many similar stories heard during the study:

I was going to collect children from the school, I was covering my head. I saw five or six boys standing at the street corner. When they saw me, they said 'Stupid Muslims! Stupid.' I was very scared, I thought they will come and hit me with a stone or something, they were so many boys and I was all alone. So I changed my path, I walked through a different street ... It was the first time that such a thing happened with me in all these years. (Shamima)

Shamima (50) was a part-time childminder working for a Muslim family in London. In her view, her experience reflected those of many working women in London. The covering of the head had clearly identified her as a Muslim. She drew a direct link between her Muslim identity and the occurrence of this incident. Similar threats to security associated with the hijaab had even led some women to think about abandoning the hijaab, or at least the traditional Pakistani dress, the shalwar kameez. None of the participants actually reported having done so, but some said that they would abandon the shalwar kameez if circumstances got worse; the hijaab, however, was not to be compromised in any event. To deal with the threats faced due to their dress code, the women used various alternatives to ensure security: they changed routes or sometimes avoiding going out entirely. With the passage of time, family members had resumed their normal routines, but the fear persisted: many exchanged frequent text messages and phone calls to ensure each other's safety.

Other forms of threat to personal security included a 'change in the looks of people', name-calling, spitting and hitting. Some women had had to undergo special checks at airports or in shopping malls to ensure that they were not carrying bombs. Hanifa, who claims to have a very good relationship with her non-Muslim neighbours, sensed an absence of smiles 
on their faces. She felt that women who would once stop to admire the colour and design of her shalwar kameez would now avoid eye contact: the clothing now only signalled that she was a Muslim. Saira (26), a young housewife with two small sons, felt that the bags of groceries lying at the bottom of her son's pushchair were looked upon with suspicion by the people at bus stops.

Women reported that relatives or friends had faced even more serious threats. These stories were all believed to be true and were narrated with conviction. Romana (37) told of a pregnant Muslim woman wearing a jilbaab (loose, full-body gown) who was beaten by boys on a bus. Nazima (25) said that on the day of the bombings, someone shouted at her aunt: 'Hey Paki, thanks for this morning, go back!' Women's husbands had been called 'Pakis' and suffered other comments of a racial nature at their workplaces. The men had found that their Pakistani origin was a barrier to finding jobs. Relatives were reported to have been deported from airports on account of their Pakistani nationality. Madiha shared the case of relatives whose boys were arrested in London on suspicion of involvement and released after two weeks.

The women's responses to such incidents and reports of incidents varied from ignoring them to planning to go back to Pakistan. Many families had been prompted to discuss this option, and most regarded the media as the key decisive factor. Nargis (48) and Kokab (54) had been living in the UK for more than 20 years:

Nargis: If [the] media keeps saying such things about Muslims, we'll have to leave this country.

Nargis: My husband and I think we should have a home in Pakistan, so if anything goes wrong here, we can go back. We don't really want to go back but when we won't have any option, we will have to go.

Kokab: We may find it easier to settle there, but it will be extremely difficult for our children as they have been born and brought up here. They are not ready to go. They say, 'We are not Pakistanis, we are British.'

Such views raise important questions of identity and belonging, as the consequences of $7 / 7$ threaten to break their long-built bonds with Britain, with still more severe implications for their children. Nargis firmly believed that the backlash against Muslims could have been avoided if the media had not portrayed the terrorists as Muslims. As Kokab said, her children's readjustment in Pakistan would be extremely problematic. The first generation of Muslim migrants did aspire to return home after earning sufficient money (Anwar, 1979), but not the younger generations, who assert their identity as British. Indeed, as we have seen, even the women not born in the UK identified themselves as British and considered Britain to be their home. Incidents that point to them as outsiders were described as 'painful and sad'.

For the participants, the media created insecurities, making them question their identities and realize that the British part of their identity may 
not be very enduring. When the prime minister Tony Blair spoke of Muslims in the UK as British citizens, this confirmation of their identity and citizenship came as a great relief. ${ }^{2}$ So too did President Musharraf's speech, stressing that the terrorists were not Pakistanis. This might suggest that being Pakistani is as important to them as being British, or that, in a difficult situation such as this, they were reverting to the identities that helped. Key arguments on 'identity' are relevant here. Identity is a fluid concept: people have multiple identities which are flexible, adaptable and capable of taking different forms according to the demands of their lives (Barth, 1969) and social experiences (Eriksen, 1993; Mauss, 1960). A typical reaction to insecurities is withdrawal from a particular identity (Eriksen, 2005). The participants adhered to their British identity when Pakistanis were being criticized as terrorists, as this had very direct implications for their security. Yet since being Pakistani remains a valued part of their identity, a declaration that the terrorists were not Pakistanis relieved them.

\section{Conclusion}

The media enable imaginings not only of the nation (Anderson, 1991; Ginsburg et al., 2002; Mankekar, 1993) but also of spaces beyond national borders. Muslims in Britain feel some anxiety about cultural loss (Anwar, 1979; Modood, 1997). As Eriksen (2005) suggests, migrants remain faithful to tradition because its familiar feel and smell gives them a sense of security and a clear, safe identity: thus women prefer apna and Islamic media, and want their children to engage with Urdu channels. However, their engagement with western media is an attempt to integrate with British society and to reinforce a new sense of belonging which they have developed over time. Conversely, Islamic media strengthen Muslim identity. Hence, the three types of media perform distinct functions in the construction of their multiple identities as women who are, as Werbner (2002) argues, simultaneously Muslims, Pakistanis and westernized. They manage these identities by creating different symbolic domains of activity and keeping these domains separate.

A typical reaction to the 'cold breath of chronic insecurity' is withdrawal (Eriksen, 2005: 16). The findings of this study question this view. Instead of withdrawing, Pakistani women are asserting their British identity and questioning what they describe as 'injustices'. They actively participate in the discourses of media and politics, turning towards their religion and families for frameworks through which they can interpret the news and find ways of attaining security.

The women's willingness to express their views did not depend on age, generation, education, language or ethnicity. However, the women coming from families where male members have been involved in politics in Pakistan or Britain, or those with highly-educated children, participated most actively. It is generally assumed that education is a decisive factor in 
determining media and political literacy, but the conclusion of this study is that something more than education enables women to question and analyse how media and politics work. Less-educated women gain wisdom from the political cultures of their families, or the knowledge of family members, and strong commitments (to Islam and/or to Pakistan) are also factors which motivate women to question what happens around them.

The social standing of Muslim women is studied in many parts of the world. These particular Muslim women do not seem to be oppressed by patriarchal systems. British Pakistani women appear very much capable of constructing and asserting their identities, gaining support and security from religion and family. News serves as an important link between men and women within their community. Beyond that community, the insecurities and threats that it faces have remained largely unheard and unseen by the national and international public. Despite attempts to resist media stereotyping, reproduction of negative discourses continues, and the media reinforcement of stereotypes intensifies a sense of injustice and Muslim victimization. Despite increasing recognition that Muslim women's voices should be heard, they all too rarely are.

\section{Notes}

1. President Musharraf, speaking on the BBC's Newsnight during a visit to London in September 2006, was reported in UK newspapers as saying:

Youngsters ... happen to come to Pakistan for a month or two months, and you put the entire blame on these two months ... and don't talk about the 27 years or whatever they are suffering in your country. (The Guardian, 2006)

2. The participant was referring to Tony Blair's speech to the Labour Party Conference on 16 July 2005, in which he said:

Within Britain, we must join up with our Muslims [sic] community to take on the extremists ... Next week I and other party leaders will meet key members of the Muslim community. Out of it I hope we can get agreed action to take this common fight forward. I want also to work with other nations to promote the true face of Islam worldwide.

(Blair, 2005)

\section{References}

Abu-Lughod, L. (1986) Veiled Sentiments: Honor and Poetry in a Bedouin Society. Berkeley: University of California Press.

Afshar, H. (1985) 'The Legal, Social and Political Position of Women in Iran', International Journal of the Sociology of Law 13: 47-60.

Anderson, B. (1991) Imagined Communities: Reflections on the Origin and Spread of Nationalism. London: Verso.

Anwar, M. (1979) The Myth of Return. London: Heinemann.

Archer, L. (2002) 'Change, Culture and Tradition: British Muslim Pupils Talk about Muslim Girls' Post-16 Choices', Race, Ethnicity and Education 5(4): 359-76. 
Barth, F. (1969) 'Introduction', in F. Barth (ed.) Ethnic Groups and Boundaries: The Social Organization of Cultural Difference, pp. 9-38. Oslo:

Universitetsforlaget.

Berthoud, R., T. Modood and P. Smith (1997) 'Introduction', in R. Berthoud,

T. Modood and P. Smith, Ethnic Minority in Britain: Diversity and

Disadvantage, pp. 1-17. London: Atheneum.

Blair, T. (2005) 'Speech on Terror', BBC News Online, 16 July. [Accessed 19

February 2007: http://news.bbc.co.uk/1/hi/uk/4689363.stm]

Bodman, H.L. and N. Tohidi (1998) Women in Muslim Societies: Diversity within Unity. Boulder, CO: Lynne Rienner.

Dupuis, A. and D.C. Thorns (1998) 'Home, Home Ownership and the Search for Ontological Security', The Sociological Review 46(1): 24-47.

El-Guindi, F. (1981) 'Veiling Infitah with Muslim Ethic: Egypt's Contemporary Islamic Movement', Social Problems 28(4): 465-85.

Eriksen, T.H. (1993) Ethnicity and Nationalism: Anthropological Perspectives. London: Pluto Press.

Eriksen, T.H. (2005) 'Risking Security: Paradoxes of Social Cohesion', inaugural lecture at the Free University of Amsterdam, The Netherlands, 15 March. [Accessed March 2007: http://folk.uio.no/geirthe/Security.html]

Fernea, E.W. (1998) In Search of Islamic Feminism: One Woman's Journey. New York: Doubleday.

Ghazal Read, J. and J.P. Bartkowski (2000) 'To Veil or Not to Veil? A Case Study of Identity Negotiation among Muslim Women in Austin, Texas', Gender and Society 14(3): 395-4.17.

Ginsburg, F., D. Abu-Lughod and B. Larkin (2002) Media Worlds: Anthropology on New Terrain. Berkeley: University of California Press.

Halstead, M. (1986) The Case for Muslim Voluntary-Aided Schools: Some Philosophical Reflections. Cambridge: The Islamic Academy.

Mankekar, P. (1993) 'National Texts and Gendered Lives: An Ethnography of Television Viewers in a North Indian City', American Ethnologist 20(3): 543-63.

Mauss, M. (1960) Sociologie et anthropologie. Paris: Presses Universitaires de France.

Modood, T. (1997) 'Ethnic Diversity and Disadvantage' in R. Berthoud, T. Modood and P. Smith, Ethnic Minority in Britain: Diversity and Disadvantage, pp. 339-59. London: Atheneum Press.

Moghadam, V.M. (ed.) (1994) Gender and Nationality: Women and Politics in Muslim Society. London: Zed Books.

Odeh, L.A. (1993) 'Post-Colonial Feminism and the Veil: Thinking the Difference', Feminist Review 43: 26-37.

Shaw, A. (2000) Kinship and Continuity: Pakistani Families in Britain. Singapore: Overseas Publishers Association.

The Guardian (2006) 'Furious Musharraf Rejects al-Qaida links' (29 Sept.). [Accessed March 2007: http://politics.guardian.co.uk/foreignaffairs/ story $/ 0,1884164,00 . \mathrm{html}]$

Werbner, P. (1990) The Migration Process: Capital, Gifts and Offerings among British Pakistanis. Oxford: Berg.

Werbner, P. (2002) Imagined Diasporas among Manchester Muslims: The Public Performance of Pakistani Transnational Identity Politics. Oxford: James Currey. 


\section{Biographical note}

Sadaf Rizvi is a doctoral student at the Institute of Social and Cultural Anthropology, University of Oxford. She has an MSc in Anthropology from Quaid-i-Azam University, Islamabad, Pakistan and an MPhil in Social Anthropology from Oxford. Previously she has been associated with the Institute for Education Development, Aga Khan University, Pakistan. Her current research is on 'Muslim Schools in Britain: Socialization and Identity'. A D D R E S S: Institute of Social and Cultural Anthropology, 51-53 Banbury Road, University of Oxford OX2 6PE, UK. [email: sadaf.rizvi@green.oxford.ac.uk] 